\title{
SUSTAINABLE EDUCATION ASSESSMENT ABK VIEWED FROM THE CONDITION PHYSICAL CHARACTERISTICS OF REGIONAL, SOCIAL, AND ECONOMIC COMMUNITY IN UNDERDEVELOPED AREA RANAH BATAHAN, PASAMAN BARAT DISTRICT, INDONESIA
}

\author{
*Arsida Nur ${ }^{1}$ and Nur Azizah Safii ${ }^{2}$ \\ ${ }^{1}$ Graduate Program of Geography Education \\ Faculty of Social Science, Universitas Negeri Padang, Indonesia \\ ${ }^{2}$ Malaya University, Malaysia \\ Email: arsidanur26@gmail.com
}

*Corresponding Author, Received: November 12, 2018, Revised: December 10, 2018, Accepted: December 21, 2018

\begin{abstract}
The problem in this research study originated from education of $\mathrm{ABK}$ in the rural area, Ranah Batahan Sub-district of Pasaman Barat. There were many problems related to the continuity of education of $\mathrm{ABK}$ in this area. The research used mixed method (combined) to collect the data besides. It conducted an observations and interviews to reinforce the data. The respondents were chosen by using total sampling and for the techniques of data analysis; it used reduction, display, verification test of validity and reliability. To find the solution of this problem the researcher with a FGD (focus group discussion) together with principals, teachers, and UPTPD of Ranah Batahan Subdistrict. From the research the result showed that the physical characteristic of the area was difficult to reach. From the social side, the research showed that there is not enough concern guides by the parents of ABK. So that ABK had a low motivation to continue their study. Besides, there were problem in economic community education the research showed. In this area, most of the people had a problem related to the cost for the education of ABK. It was also constrained to the sustainability of education of ABK. So that it was important to give an effort to continuity education of ABK in Ranah Batahan Sub-district. For example, it was conducted by building a SLB together with the parents of ABK, people, head master, and also the government.
\end{abstract}

Keywords: Education, ABK and Rare Areas 


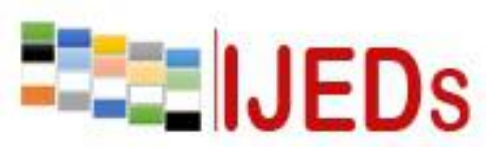

http://ijeds.ppj.unp.ac.id/index.php/IJEDS
International Journal of Educational Dynamics

Vol. 1 No. 1 (pp. 1-9) December 2018

p_ISSN 2655-4852

e_ISSN 2655-5093

\section{INTRODUCTION}

Continuity of education was held for continuing and expanding of education also preparing children become members of society who have the ability to conduct a mutual relationship to the social environment, culture, and nature, and be able to develop more capability in the world of work and the next level of education (Hermon and Dalim, 2005; Hermon and Dalim, 2006; Hermon, 2015). Total ABK in Sumatera Barat are 25.008 people while only 1,345 people who touched formal education. Totally number of ABK in Pasaman Barat is 582 people while only 213 people who received formal education. The schools for $\mathrm{ABK}$ in Pasaman Barat located in the center of district consist of 129 members and the other school located in Sungai Aur that have 84 members of ABK. There are 73 people of ABK in the Ranah Batahan Sub-district District of Pasaman Barat especially in the rare area related to the problem of continuity education. The are many problems related to the continuity education of $\mathrm{ABK}$ in the Ranah Batahan Sub-district District of Pasaman Barat. It was marked by a lack of education obtained and a number of $\mathrm{ABK}$ who do not have a chance to continue the next level of education. In this area there were many districts that have many of ABK that did not have a chance to continue their education, even though if they fostered and empowered they have high potential.

The results of observations showed a lot of education ABK delayed, even some of them have never been gotten education. Most of ABK have interest and high motivation to continue their education, but sometimes parents have a low view to the potential of $\mathrm{ABK}$ and also the costs for continuing education $\mathrm{ABK}$ is quite expensive. Understanding of parents who are still low on the obligation to provide the opportunity and give a same needed is one of the factors of sustainability education ABK delayed. The low opportunity for continuing education ABK is generally caused by the condition of the physical characteristics of rare areas, social, and economic communities in rare areas Ranah Batahan Sub-district, Pasaman Barat District.

Based on the background above, it was sustainability factor of ABK educational in underdeveloped areas Ranah Batahan Sub-district, Pasaman Barat affected by physical characteristics, social and economic. In this case, the authors are interested to assess the problem that is poured into a title "sustainability education 


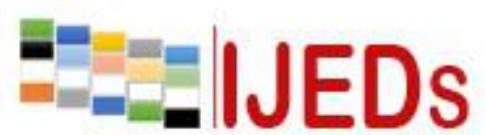

http://ijeds.ppj.unp.ac.id/index.php/IJEDS

assessment $\mathrm{ABK}$ viewed from the condition physical characteristics of regional, social, and economic community in underdeveloped area in Ranah Batahan, Pasaman Barat.

\section{METHOD}

The type of research used in this study was mixed Method. The technique of data collection was through observation, interviews, documentation, questionnaire and FGD. The data analysis used in this study was a quantitative and qualitative analysis technique. Qualitative analysis techniques including: (1) Data reduction. The data obtained from the field, so it should be noted in detail, (2) Presentation of data (display data), the data obtained were categorized according to subject matter created in the form of a matrix, short description, charts, and the relationships between categories, (3) Verification (conclusion) is the meaning of the data that has been collected, (4) Credibility test, and (5) The accuracy and validity of data collected and analyzed since the beginning of the study will determine the correctness and accuracy of the results of research in accordance with the issue and focused study. A technique of quantitative was analyzed by description of the data according to the type of research that is the percentage can be calculated by using the following formula:

$\mathbf{P}=\mathbf{F} / \mathbf{N} \times 100$

Description:

$\mathrm{P}=$ Percentage

$\mathrm{F}=$ Frequency response

$\mathrm{N}=$ Number of respondents

\section{RESULTS AND DISCUSSION}

A region will be left behind caused by several improper policies, such as the lack of development in the underdeveloped areas, fault approaches and development priorities, also traditional community institution were not involved in the planning of development. First, from the geographical characteristics underdeveloped areas Ranah Batahan Sub-district was relatively difficult to reach for about $91,78 \%$ area in the hilly. 


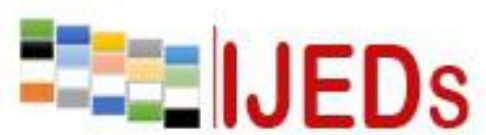

http://ijeds.ppj.unp.ac.id/index.php/IJEDS
International Journal of Educational Dynamics

Vol. 1 No. 1 (pp. 1-9) December 2018

p_ISSN 2655-4852

e_ISSN 2655-5093

Many areas in the hills made a trouble for ABK parents to send their children going to school. The steep topography made it difficult for people to do their daily live. The distance to SLB was also one of the constraints for the people because of the distance from underdeveloped areas to SLB on average $52 \mathrm{~km}$. In addition, the steep topography was also threatening underdeveloped areas with landslide hazards and threatened by the danger of flooding. Second, from the natural resources of ABK parents would determine the sustainability of ABK education. The natural resources are rubber and palm oil that functions as a source to fulfillment of economic and the daily needs. But in this case, the selling power of oil palm and rubber are very cheap so makes ABK parents difficult to meet the needs especially for education. The price of palm oil generally was $\mathrm{Rp} 900 / \mathrm{Kg}$, but in this area the price was only $\mathrm{Rp} 600 / \mathrm{Kg}$, while the price of rubber was $\mathrm{Rp} 4,500 / \mathrm{Kg}$, in this area the price only $\mathrm{Rp} 3.500 / \mathrm{Kg}$.

Third, in terms of human resources is essential for the sustainability of agriculture and education also generates quality of human resources. Human resources in underdeveloped areas Ranah Batahan Sub-district was still low. It was characterized by the number of ABK parent education. ABK parent who graduated from elementary school was 30,14\%, graduated from junior high school was 36,99\%, graduated from high school was $12,32 \%$ even though there were some who did not graduate from elementary school amount $20,55 \%$.

Forth, the transportation that could be used to achieve the area is just a twowheeled transportation. In case of heavy rain it cannot be crossed because the path is a dirt road. While, the bridge construction has not been conducted, it could be an obstacle for citizens to conduct their daily activities. Especially during a broken of bridge, the transportation to cross is "Getek" (raft). In the under developed areas, had not all of people get the irrigation flow, is a major obstacle for people who has a job as a farmer. The ABK parents use a system rice to plan rice. There is no other way that can chose by ABK parents except choosing gardening rubber and palm oil.

Fifth, the communication conditions were also highly affect in the sustainability of $\mathrm{ABK}$ education, because communication could remind of ABK parents to be more developed and can compare with $\mathrm{ABK}$ in other regions. The communication can by television, hand pone, radio and others. But most of the area was using only the 


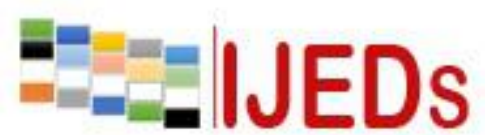

http://ijeds.ppj.unp.ac.id/index.php/IJEDS

river as a power for lighting while PLN not already signed into those areas. Sixth, the area was underdeveloped caused by some an improper policy, such as: the government does not favor the development of underdeveloped areas and traditional institutions do not be involved in planning and the development of region. In fact, there were no attentions from the local government to solve problems in underdeveloped areas in terms of both formal and non-formal education for ABK.

Sustainability of ABK education in this study has not materialized caused of many ABK who did not continue their education. ABK education should be get more attention the parents have an important role in the sustainability of ABK education. In fact, the parents give up and even desperate to provide sustainability education for ABK. They also preoccupied with their economic needed and makes ABK got careless. The physically underdeveloped areas were one of the constraints faced by the ABK to continue their education to a higher level that appropriate with the levels. There is difficult topography of the area consisting of steep mountains and ramp makes ABK disrupted to go school or studying. There should always existed ABK parents who are always drop off and pick them up for school. In addition, the distance was between the nearest to SLB underdeveloped areas about $50 \mathrm{~km}$.

In addition to fulfilling the daily live and the economy live the ABK parents have to work for finance the education of children as well as the finance of ABK education. They were most of ABK cannot attend the school in underdeveloped areas of Ranah Batahan Sub-district due to for several factors, including the distance from home to school is quite far and costs for school is expensive, and also the minds of the people who still perceive the education is not required for $\mathrm{ABK}$ and does not ensure the better future.

The first parents, parents should learn more about how to educate and guide the ABK. Parents are the better informed and more understand about the importance of service dedicated to the ABK. Caring parents is preferred for sustainability education ABK. Parents should motivate the ABK to learn and also have positive thinking towards ABK. The myth in society about the perception that states ABK does not have the ability to be proud should be eliminated. The second teachers in schools should understand the provisions rights conventions of Children who have signed by all of 


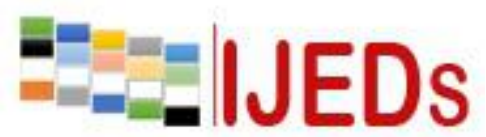

http://ijeds.ppj.unp.ac.id/index.php/IJEDS

\section{International Journal of Educational Dynamics}

Vol. 1 No. 1 (pp. 1-9) December 2018

p_ISSN 2655-4852

e ISSN 2655-5093

governments in the world that all children have the right to learn. Teachers should willingly accept the children who want to study, as well as in the Ranah Batahan Subdistrict there was no SLB available. So the teacher should to accommodate all children regardless of their physical, intellectual, social, emotional, linguistic and other conditions.

The third, the head master was as government partners to support the implementation of the handling $\mathrm{ABK}$, to build public awareness and parents about the rights of $\mathrm{ABK}$ and also participate in the making of inclusive schools, raise awareness to the committee of school and students to care and protection of $\mathrm{ABK}$, to support and facilitate $\mathrm{ABK}$ potential in the field of sports, arts and education. The fourth, the ministry of education and culture (Kemendikbud) participate in the development of training institutions and coaching for parents of $\mathrm{ABK}$, share the information and the right of handling $\mathrm{ABK}$, disseminating laws and policies related to the handling of $\mathrm{ABK}$ and to advocate and monitor the implementation of policies, disseminate the right information and the way to handling children with special needs, socialize resource center on inclusive education for $\mathrm{ABK}$, providing the inclusive education evenly, allocating the SLB/ SDLB with a good infrastructure and facilities, improving the ability of teacher, availability of information access about the ABK education programs. In addition, there were also government budget for the cost of sustainability for education of ABK. The fifth, the ministry of health (Moh), the health care before marriage to the community, the health care facilities that are friendly to $\mathrm{ABK}$, there are convenience access to healthcare for ABK through the provision of health cards, the availability of specialist health services for ABK and budget for health care for a ABK. The sixth, ministry of social affairs (Mosa) participate in doing social control will be the government's policy on the handling of $\mathrm{ABK}$ and implementation. Any child protection law, ministry of social affairs also needs to receive and act on reports of violence, discrimination and exploitation that occur in $\mathrm{ABK}$. 


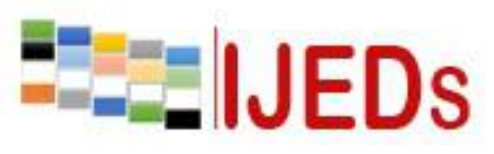

http://ijeds.ppj.unp.ac.id/index.php/IJEDS
International Journal of Educational Dynamics

Vol. 1 No. 1 (pp. 1-9) December 2018

p_ISSN 2655-4852

e_ISSN 2655-5093

\section{CONCLUSION}

Based on the research conducted in the study about the sustainability education of $\mathrm{ABK}$ in terms of the physical characteristics area, the social and economic in the underdeveloped areas of Ranah Batahan Sub-district, Pasaman Barat, it could be concluded some of the following: The problem of sustainability education of ABK in terms of the physical areas were difficult to reach by the public to the sub-district center due to the distance from developed areas into sub-district center an average of $12 \mathrm{~km}$ coupled with steep topography potential as areas prone to landslides caused this area was hard to reach. The problems of sustainability education in terms of the ABK characteristics were the physical characteristics of ABK. The most of ABK were a mental retardation amount 23 people $(31.51 \%)$, there were 11 people $(15.07 \%)$ characterized as quadriplegic, 2 people $(2.74 \%)$ characterized as the visually impaired, 2 people $(2.74 \%)$ with the characterized as hearing impairment, 18 people $(24.66 \%)$ the characterized of poor children, and 17 people $(23.29 \%)$ characterized as children learning disabilities. The problems of sustainability education in the social characteristics of ABK parents viewed by indifferent and parents level of education were graduated from elementary and junior high school and even many ABK parents who did not graduate from elementary education. This is due to the mindset of the people who are still traditional, the difficult economic, environmental influences and lack of knowledge about the importance of education. The constraints of sustainability education of $\mathrm{ABK}$ in terms of the condition of the physical characteristics, social, and economic communities in the underdeveloped areas in Ranah Batahan Sub-district Pasaman Barat. The constraints of conditions influenced by the physical characteristics of the topography of the area and the difficulty in reaching areas of ABK, make parents and communities have constraints in terms of cost, time and effort to go to the SLB. While the condition of social characteristics seen by age and parental education of ABK. The efforts to follow up the sustainability education of $\mathrm{ABK}$ in the underdeveloped areas in Ranah Batahan Sub-district Pasaman Barat are not found yet, either from parents, schools, communities, local government, health authorities and others. 


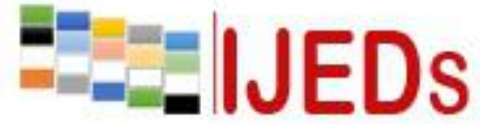

http://ijeds.ppj.unp.ac.id/index.php/IJEDS
International Journal of Educational Dynamics

Vol. 1 No. 1 (pp. 1-9) December 2018

p_ISSN 2655-4852

e ISSN 2655-5093

\section{REFERENCES}

Abdullah, N. 2013. Mengenal Anak Berkebutuhan Khusus. Jurnal Anak Berkebutuhan Khusus. Magistra No. 86 Th. XXV Desember 2013.

Abdurrahman, M. 2012. Anak Berkesulitan Belajar. Jakarta: Rineka Cipta.

Alimin, Z. 2004. Reorientasi Pemahaman Konsep Pendidikan Khusus Pendidikan Kebutuhan Khusus dan Implikasinya terhadap Layanan Pendidikan. Jurnal Asesmen dan Intervensi Anak Berkebutuhan Khusus. Vol.3 No 1 (52-63).

Amin dan Dwidjosumarto. 1979. Pengantar Pendidikan Luar Biasa. Jakarta: New Aqua Press.

Arikunto, S. 2012. Prosedur Penelitian Suatu Pendekatan Praktik. Jakarta: Rineka Cipta.

Anggraini, R. R. 2013. Persepsi Orang tua Terhadap Anak Kebutuhan Khusus (Deskriptif Kuantitatif di SDLB N.20 Nan Balimo Kota Solok. Pendidikan Khusus.Vol 1 No 1. Jurnal.

Badan Pusat Statistik. 2010. Ranah Batahan Sub-District of Pasaman Barat.

Bappenas. 2006. Seminar Nasional Percepatan Pembangunan Sosial Ekonomi Daerah Tertinggal. Dit. Kawasan Khusus dan Daerah Tertinggal.

Baswori, S. 2008. Memahami Penelitian Kualitatif. Jakarta: Rineka Cipta.

Cropley, A.J. 1994. Pendidikan Seumur Hidup Suatu Analisis Psikologis. terjemahan. sardjan kadir. tanpa tahun. Surabaya. Usaha Nasional.

Efendi, M. 2009. Pengantar Psikopedagogik Anak Berkelainan. Jakarta: Bumi Aksara.

Elisa, S and W. A. Tri. 2013. Sikap Guru Terhadap Pendidikan Inklusi Ditinjau dari Faktor Pembentuk Sikap. Psikologi Perkembangan. Vol 2 No 1. Jurnal.

Hadis, A. 2006. Pendidikan Anak Berkebutuhan Khusus-ABKtik. Bandung: Alfabeta.

Hermon, D and Y. Dalim. 2005. Penggunaan Media Audio Visual untuk Meningkatkan Kreatifitas Belajar. Jurnal Pembelajaran. Vol. 28. Issue 3. p. 266-276.

Hermon, D and Y. Dalim. 2006. Penerapan Kuliah Lapangan untuk Meningkatkan Hasil Belajar Mahasiswa. Forum Pendidikan. Vol. 28. Issue 3. p. 156-161.

Hermon, D. 2015. Arahan Kebijakan Keberlanjutan Pendidikan 10 Tahun Pasca Bencana Tsunami di Kabupaten Aceh Jaya Provinsi Aceh. Seminar Nasional Geografi. Master Program of Geography Education, Universitas Negeri Padang

Hidayat. 2009. Model dan Strategi Pembelajaran ABK dalam Setting Pendidikan Inklusi. Jurnal Pengenalan \& Identifikasi Anak Berkebutuhan Khusus dan Strategi Pembelajarannya.

Ishartiwi. 2009. Model Inklusif Layanan Khusus Pembinaan Siswa Cerdas Istimewa Berbakat/Istimewa Berbasis Sumber Daya Daerah. Jurnal Pendidikan khusus Vol 5 No 2.

Iswari, M. 2008. Kecakapan Hidup Bagi Anak Berkebutuhan Khusus. Padang: UNP Press.

Maftukhah. 2007. Pengaruh Kondisi Sosial Ekonomi Orang Tua Terhadap Prestasi Belajar Siswa Kelas VII SMP n 1 Randudongkal District of Pemalang Tahun 2006/2007. Skripsi. Universitas Negeri Semarang.

Marlina. 2009. Asesmen Pada Anak Berkebutuhan Khusus. Padang: UNP Press.

Mundar, M. 2003. Layanan Bimbingan bagi Anak Berkebutuhan Khusus di Sekolah Dasar Wilayah Kota Bandung, Tesis, Program BP-BAK PPs UPI Tahun 2003. 
http://ijeds.ppj.unp.ac.id/index.php/IJEDS

Pramana, P. E. 2015. Dampak Program Bantuan Sosial Terhadap Pertumbuhan Ekonomi dan Kemiskinan District of Tertinggal di Indonesia. Vol 17 No 3.

Praptiningrum, N. 2010. Fenomena Penyelenggaraan Pendidikan Inklusif Bagi Anak Berkebutuhan Khusus. Jurnal Pendidikan. Vol 7 No 2.

Rudiyati, S. 2012. Penanganan Anak Berkebutuhan Khusus Berbasis Akomodasi Pembelajaran. Tesis. Yogyakarta: Universitas Negeri Yogyakarta.

Smith, J. D. 2012. Konsep dan Penerapan Pembelajaran Sekolah Inklusif. Bandung: Nuansa.

Sudjana, N and Ibrahim. 2004. Penelitian dan Penilaian Pendidikan. Bandung: Sinar Baru.

Sumaatmadja, N. 1982. Pengantar Ke Arah Pendidikan Lingkungan. Bandung: FKIS IKIP

Sumekar, G. 2009. Anak Berkebutuhan Khusus. Padang: UNP Press.

Santoso, H. 2012. Cara Memahami dan Mendidik Anak Berkebutuhan Khusus. Yogyakarta: Katalog Dalam Terbitan.

Soerjani, M. 2000. Kepedulian Masa Depan. Jakarta : Institut Pendidikan Dan Pengembangan

Sugiyono. 2010. Metode Penelitian Kuantitatif Kualitatif Dan R\&D . Bandung: Alfabeta.

Sugiyono. 2012. Metode Penelitian Kuantitatif, Kualitatif dan Kombinasi (Mixed Method). Bandung: Penerbit Alfabeta.

Sugiyono. 2014. Metode Penelitian Manajemen. Bandung: Alfabeta.

Suparno and P. Heri. 2000. Karakteristik Anak Berkebutuhan Khusus. Jurnal Pendidikan Khusus Vol 4 No 2.

Sutaat. 2010. Masalah, Potensi, dan Sumber daya Sosial Daerah Tertinggal (Studi Kasus Village of Buwunmas, Kecamatan sekotong- District of Lombok Barat). Jurnal Penelitian dan Pengembangan Kesejahteraan Sosial, Vol. 15 No. 01, 2010 : 5971.

Suwandi dan Basrowi. 2008. Memahami Penelitian Kualitatif. Jakarta: Rineka Cipta.

Syahza, A dan Suarman. 2013. Strategi Pengembangan Daerah Tertinggal dalam Upaya Percepatan Percepatan Pembangunan Ekonomi PeVillage ofan. Jurnal Ekonomi Pembangunan Vol 14 No 1.

Tarmansyah. 2009. Perspektif Pendidikan Inklusif Pendidikan untuk Semua. Padang: UNP Press.

Tashakkori, A and Teddlie, C. 2003. Mixed Method. California. Terjemahan Oleh Daryatno. Jakarta: Pustaka Pelajar.

Tirtonegoro, S. 1984. Anak Super Normal dan Program Pendidikannya. Jakarta: Bina Aksara.

Undang-Undang Nomor 20 Tahun 2003 Tentang Sisitem Pendidikan Nasional Indonesia.

Waedi. 2009. Pengaruh Usia Terhadap Produktivitas Kerja Pegawai Garmen PT. Primatex District of Batang Tahun 2009. Skripsi. Universitas Negeri Semarang. 